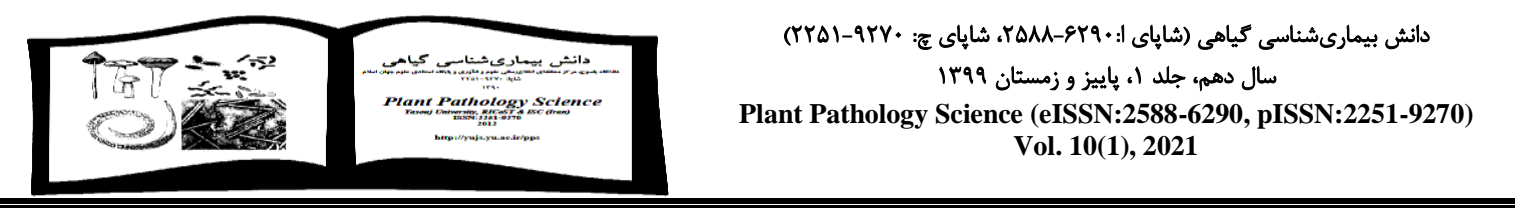

Research Article

\title{
The impact of Chinaberry, Colocynth and Camelthorn extracts on eight bacteria and three fungi
}

SAEID GHAHARI ${ }^{1}$, SOMAYEH GHAHARI ${ }^{2}$, SAJJAD GHAHARI ${ }^{3}$, GHORBANALI NEMATZADEH ${ }^{2}$

1. Department of Agriculture, Shahed University, Tehran, Iran.

2. Genetics and Agricultural Biotechnology Institute of Tabarestan (GABIT), Sari Agricultural Sciences and Natural Resources University, Sari, Iran.

3. Department of Biology, Faculty of Science, Shahid Chamran University of Ahvaz, Ahvaz, Iran.

Received: 02.01.2021

Accepted: 12.05.2021

Ghahari S, Ghahari S, Ghahari S Nematzadeh GH (2021) The impact of Chinaberry, Colocynth and Camelthorn extracts on eight bacteria and three fungi. Plant Pathology Science 10(1):14-26. Doi: 10.2982/PPS.10.1.14.

\section{Abstract}

Introduction: Antibacterial, antifungal and antioxidant activity of methanolic extracts of Colocynth (Citrullus colocynthis) seeds, Camelthorn (Alhagi maurorum) fruit and Chinaberry (Melia azedarach) leaves on eight bacteria and three fungi, which usually cause damage to agricultural products examined in this research. Material and Methods: Antimicrobial activity of selected plants in six concentrations on 11 microorganisms including, three gram-positive bacteria vs. Bacillus subtilis, Staphylococcus aureus, and Rathayibacter toxicus, and five gram-negative bacteria vs. Escherichia coli, Pseudomonas aeruginosa, Pseudomonas syringae subsp. syringae, Pseudomonas viridiflava, and Xanthomonas campestris pv. campestris, as well as three fungi vs. Pyricularia oryzae, Fusarium oxysporum and Botrytis cinerea was measured using the disk diffusion method. Also, the antioxidant activity of the extracts of these plants was evaluated by measuring the enzymes of catalase and guaiacol peroxidase and evaluating the ability to trap DPPH radicals. In addition, the amount of total phenols and flavonoids in these plants extracts were measured. Results: Methanolic extract of Colocynth seeds had the highest antibacterial activity, the highest activity of catalase and guaiacol peroxidase enzymes and the highest percentage of DPPH radical inhibition. Methanolic extracts of these plants had no effect on fungal colony growth. Conclusion: Methanolic extract of Colocynth seeds can be considered as potential sources of bactericides in agriculture.

Key words: Bacillus, Pseudomonas, Xanthomonas

$\triangle$ Corresponding author: s.ghahary@gmail.com 


$$
\text { مقاله يزوهشى }
$$

$$
\begin{aligned}
& \text { اثر عصارههاى زيتونتلخ، هندوانه ابوجهل و خارشتر بر هشت باكترى و سه قارج }
\end{aligned}
$$

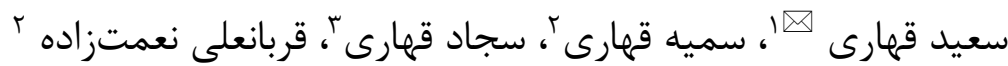

$$
\begin{aligned}
& \text { I. گروه زراعت، دانشكده علوم كشاورزى، دانشخاه شاهد تهران. } \\
& \text { r. يزوهشكده زنتيك و زيست فناورى كشاورزى طبرستان، } \\
& \text { دانشگاه علوم كشاورزى و منابع طبيعى سارى. }
\end{aligned}
$$

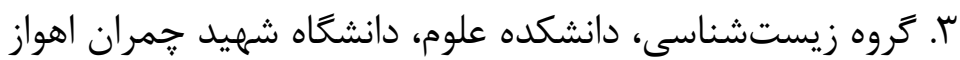

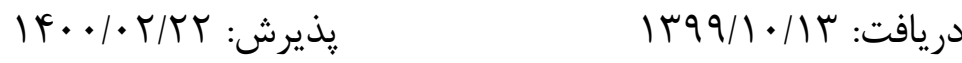

قهارى س، قهارى س، قهارى س، نعمتزاده ق (99 (I) اثر عصارههاى زيتون تلخ، هندوانسه ابوجهـل و

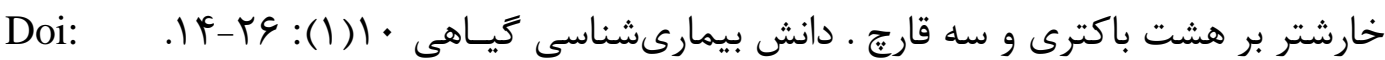

مقدمه: فعاليت ضدباكتريايى، ضدقارجى و پاداكسندهاى عصاره متانولى دانه هندوانهابوجهل Melia (Citrullus colocynthis) عليه هشت باكترى و سه قارج كه معمولاً باعث آسيب به محصولات كشاورزى مىشوند، (azedarach در اين يزوهش مورد بررسى قرار گرفت. مواد و روشها: فعاليت ضدميكروبى كياهان انتخاب شده در

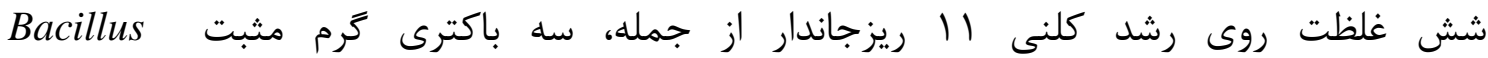
Rathayibacter toxicus و Staphylococcus aureus،subtilis ‘Pseudomonas syringae subsp. syringae ‘Pseudomonas aeruginosa ‘Escherichia coli Xanthomonas campestris pv. campestris Pseudomonas viridiflava Botrytis cinerea Pyricularia oryzae در ديسك سنجيده شد. همجنين، فعاليت پاداكسندهاى عصاره اين سه گياه با اندازهخيرى فعاليت

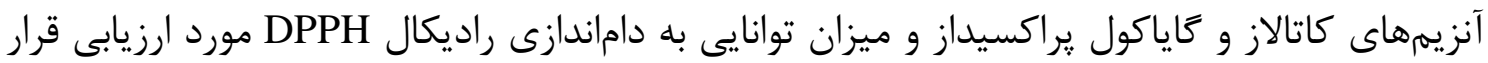

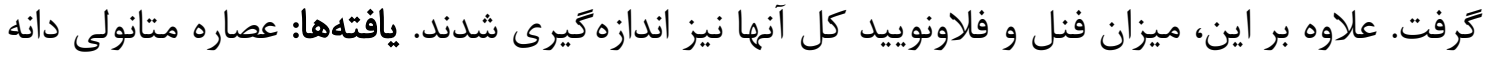
هندوانه ابوجهل داراى بيشترين فعاليت ضدباكتريايى، بيشترين ميزان فعاليت آنزيمهاى كاتالاز و

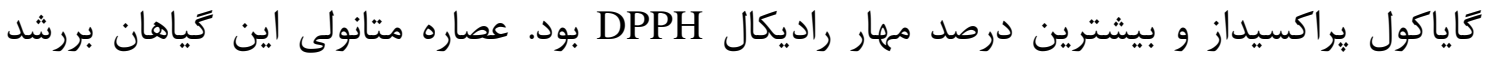

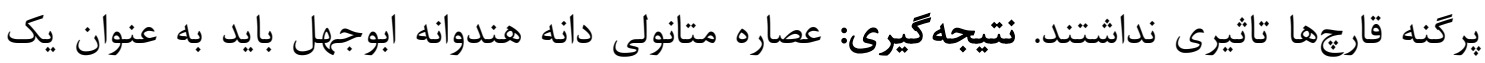
منبع بالقوه باكترى كش در حوزه كشاورزى مورد توجه قرار گيرد.

وازگًان كليدى: Bacillus, Pseudomonas, Xanthomonas

ه:ghahary@gmail.com 


\section{Introduction}

مقدمه

حفظ و نكهدارى محصولات كشاورزى در برابر بيمارىهاى كياهى به دليل تأثير زيادى كه بر كميت و كيفيت محصول كياهان مى گذارند،از هدفهاى مههم كشاورزى مدرن محسوب مىشود (Martins et al. 2012). استفاده از آفتششهاى شيميايى براى مديريت بيمارىهاى گياهى در نيم قرن اخير بسيار رايج شده است. آفتششهاى شيميايى مشكلاتى همجون خطر بروز مقاومت بيماركر هاى گياهى، افزايش هزينه توليد، مشكلات زيست محيطى و تهلديد سلامتى انسان را به همراه دارند (Garriga and Caballero 2011). بروز اين گونه مشكلات، محققين را به يافتن آفت كشهايى با خطرات زيستى كمتر، جهت جايگزينى با آفتكشهاى شيميايى موجود ترغيب نموده است (Sutherland 2002). استفاده از آفتششهاى بيولوزيك مىتواند يكى از روشهاى جايكزين مناسب در اين زمينه باشد (Baskar et al. 2009). تحقيق در زمينه عصارهاى گياهى و تركيبات شيميايى مشتق شده از آنها و نيز قابليت آنها در مهار بيماركرهاى گياهى جندين دهه است كه مورد توجه

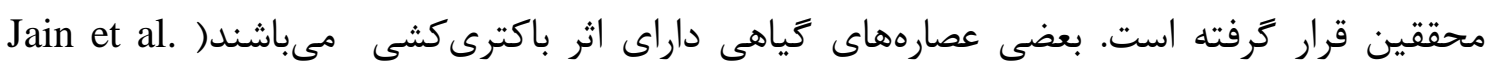

.(Rezaei 2020, 2008

هندوانه ابوجهل .Citrullus colocynthis (L.) Schrad ميوهاى تلخ مزه است كه در مناطق مختلف ايران به شكل خودرو مىرويد. در طب سنتى ايران و بسيارى از كشورها از اين گياه در درمان يبوست، ضعف اعمال روده، عفونتهاى باكتريايى، بيمارىهاى كبدى، تحريك تقويت كبد و به عنوان ضد عفونى كننده كليه استفاده شده است (Mojaz Dalfardi et al. 2015). بر اين، اين كياه اثرات ضدباكتريايى و ضدقارجى نيز دارد (Khalil et al. 2010, Benalla et al. 2010). زيتونتلخ Meliaceae متعلق به تيره Melia azedarach L.

مىشود و بومى جنوب شرقى آسيا (ياكستان، هند و جين) و استراليا مىباشد و يكى از مفيدترين كياهانى مى باشد كه از بخشهاى مختلف آن در طب سنتى استفاده مىشود (Saleem et al. 2008). خارشتر .Alhagi maurorum Medik كياهى است از تيره باقلاييان (Fabaceae) و نام ديخر آن علف ترنجبين مىباشد. ميوه اين گياه ناشكوفا است (Atta et al. 2010). ساقههاى آن سبز رنگ با خارهاى تيز نوك زرد مىباشند. خارشتر براى گياهانى مانند: غلات و جغندر به عنوان علف هرز بشمار مى آيد.

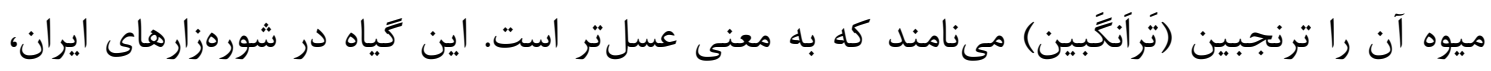
عربستان، صحراى سينا، سوريه و هند و ڤاكستان تا ارتفاع . ․ مترى از سطح دريا مىرويد

.(Atta and Mouneir 2004) 
فعاليت ضدقارجى عصاره اتانولى بخش گُل هندوانه ابوجهل عليه جهار قارج Alternaria alternata. Rizoctonia solani و Fusarium solani ،Fusarium oxysporum مورد ارزيابى قرار گرفت. بر اساس يافتههاى بدست آمده هندوانه ابوجهل بيشترين اثر بازدارندگى را روى Rolani A. alternata soladizadeh et al. 2009) نشان داد (Hadi). همجنين در تحقيق ديكرى Staphylococcus فعاليت ضدميكروبى اسانس و عصاره متانولى هندوانه ابوجهل عليه 9 باكترى Pseudomonous ‘Escherichia coli Streptococcus pyrogens ‘Bacillus subtilisaureus Proteus Salmonella typhi ‘Proteus vulgaris ‘Klebsiella pneumoniaeaeruginosa mirabilis متانولى بيشترين فعاليت ضدباكتريايى و ضدقارجى را به ترتيب عليه S. aureus و A. niger نشان دادند (Doss et al. 2011). علاوه بر اين، فعاليت ضدباكتريايى عصاره متانولى هندوانه ابوجهل عليه باكترىهاى Elebsiella Proteus mirabilis،Pseudomonas aeruginosa Eschia colic Staphylococcus aureus و مورد بررسى قرار گرفت. عصاره متانولى بيشترين فعاليت ضدباكتريايى را عليه باكترى S. aureus نشان داد (Srivastava et al. 2013). همجنين، فعاليت ضدباكتريايى عصاره متانولى دانه هندوانه ابوجهل در غلظتهاى مختلف عليه باكترى Staphylococcus aureus اثر بازدارندكى را نشان داد (Rezaie et al. 2018). در تحقيقى فعاليت ضدباكتريايى و ضدقارجى عصاره الكلى و آبى برى گياه زيتون تلخ مورد بررسى قرار گرفت. بر اساس يافته ها بدست آمده عصاره الكلى و آبى برى گياه زيتون تلخ، فعاليت ضدباكتريايى روى باكترىهاى Bacillus cereus، Pseudomonas aeruginosa, Escherichia coli staphylococcus aureus ضدقارجى عليه قارجهاى Fusarium oxysporum Aspergillus flavus Aspergillus niger و Rhizopus stolonifer زيتون تلخ بر قارج Candida albicans مورد بررسى قرار گرفت. يافته ها اين مطالعه نشان داد كه اين عصاره داراى اثر ضدقارجى مىباشد (Orhan et al. 2012). علاوه بر اين در تحقيق ديخرى، اثر ضacillus اباكتريايى عصاره آبى، اتانولى، متانولى و استونى اندام هوايى خارشتر روى باكترىهاى إنى Erwinia carotovora subsp. و Clavibacter michiganensis subsp. Sepedonicus ،subtilis r مورد ارزيابى قرار گرفت. يافتههاى يزوهش اين محققين نشان داد كه، در غلظت ميلى باشند (Abdul-Hafeez et al. 2015). 
هدف از انجام اين يزوهش بررسى فعاليت ضدباكتريايى، ضدقارجى و پاداكسندهاى عصاره متانولى دانه هندوانهابوجهل ، ميوه خارشتر و برى زيتونتلخ عليه هشت باكترى و سه قارع كه معمولاً باعث آسيب به محصولات كشاورزى مىشوند، بود.

\section{Material and Methods}

مواد و روشها تهيه نمونهها و عصارههاى گياهى در :زوهش حاضر دو گونه گَياهى هندوانه ابوجهل (دانه) و زيتون تلخ (برگ) از منطقه سارى (مازندران) و گَونه گياهى خارشتر (ميوه) از منطقه زابل (سيستان و بلوجستان) جمعآورى و به آزمايشگاه فيتوشيمى يزوهشكده زنتيك و زيست فناورى كشاورزى طبرستان منتقل و پس از شستشوى سطحى با آب مقطر در سايه و به دور از نور مستقيم خورشيد خشك شدند. سيس هر يك از اندامهاى مورد نظر، براى عمليات عصارهگيرى با آسياب برقى :ودر گرديدند Ghahari et al. 2015). عصاره متانولى گياهان، به روش ماسراسيون تهيه گرديدند (Hadadi et al. 2020). بررسى فعاليت پإاكسندهاى عصاره كياهان عصاره گياهان براى انجام اين آزمايش از هـ •/ ترم از بافت فريز شده خياهان مورد نظر در هاون جينى سرد و در ظرف يخ با ب ميلىليتر بافر فسفات //• مولار با اسيديته / / حاوى EDTA يك

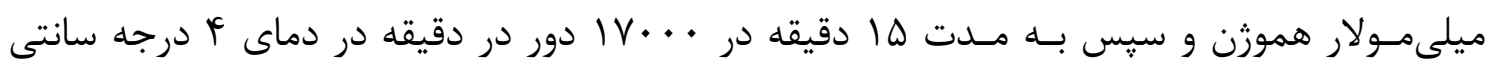
گراد سانتريفيوز گرديـدند، تهيه گرديدند. فاز بالايى (سويرناتانت) عصارههاى بدست آمده براى اندازهزيرى فعاليت آنزيمى كاتالاز، گاياكول يراكسيداز و همجنين، مقدار : يروتيينهاى محلول مورد استفاده قرار گرفت. براى اندازهيرى فعاليت آنزيمها از روش اسيكتروفتومترى استفاده گرديد

.(Ghahari et al. 2017 ،Ghahari et al. 2017 ،Ghahari et al. 2018) فعاليت آنزيم كاتالاز (CAT) با روش اسـيكتروفتومترى و بر اساس كاهش جذب يراكسيد هيدروزن

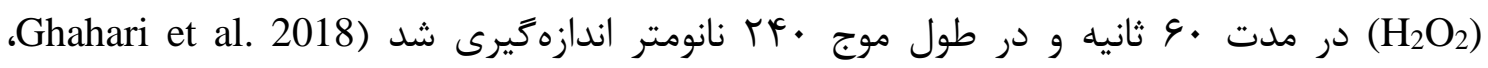

(Ghahari et al. 2017 ،Ghahari et al. 2017 فVاليت آنزيم Fاياكول يراكسيداز با روش اسـيكتروفتومترى در مدت •و ثانيه و در طول موج نانومتر اندازهيرى شد (Hadadi et al. 2020). يروتيينهاى محلول در • ه ميكروليتر از عصاره آنزيمى كه توسط آب مقطر به حجم · ․ رسيد و سيس به آن ه ميلىليتر محلول برادفورد اضافه گرديد. بعد از ورتكس نمودن و كذشت ها 
دقيقه، جذب تركيب فوق با استفاده از دستخاه اسيكتروفتومتر و در طول موج ه9ه نانومتر اندازهگيرى شد (Ghahari et al. 2018، Hadadi et al. 2020.

تعيين فعاليت ضد راديكالى با استفاده از DPPH در يك ميلىليتر از غلظتهاى مختلف عصاره

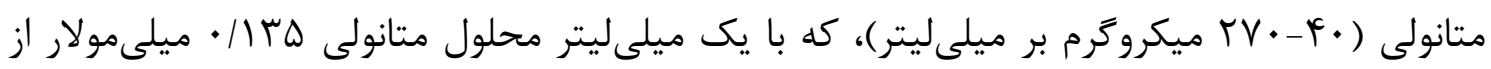
مخلوط گرديدند. محلولهاى حاصل به سرعت هم زده شدند و سيس به مدت • م دقيقه در تاريكى و در دماى اتاق قرار گرفتند و پِ از آن جذب نمونهها با استفاده از دستعاه اسيكتروفتومتر در نانومتر اندازهزيرى شدند. از اسيد آسكوربيك به عنوان استاندارد استفاده گرديد. اين آزمايش براى هر غلظت سه بار تكرار گرديد. در نهايت، ميزان IC50 (غلظتى از هر عصاره كه لازم است تا •هـ٪

راديكال ها مهار شوند) براى عصارهها تعيين گرديد (Ghahari et al. 2018). تعيين ميزان فنل كل عصاره گیاهان با روش فولين-سيو كالتو انجام شد (Hadadi et al. 2020). در نهايت، ميزان فنل كل از روى ميزان جذب نمونه و استاندارد، و بر حسب ميلى گرم اسيد كاليـك به كرم وزن خشك گياه بيان گرديد. ميزان فلاونوييد كل عصاره گياهان با استفاده از روش رنگسنجى كلريد آلومينيوم اندازهيرى شد

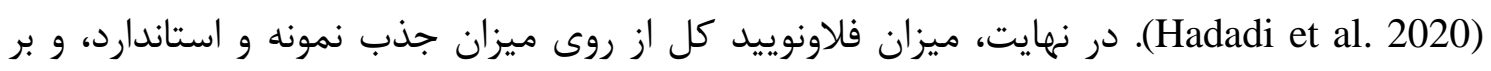
حسب ميلى گرم كوئرستين به گرم وزن خشك كياه بيان گرديد.

بررسى فعاليت ضدباكتريايى عصارههاى متانولى گياهان

باكترىهاى مورد استفاده در اين يزوهش از آزمايشگاه ميكروبيولوزى يزوهشكده زنتيك و زيست فناورى كشاورزى طبرستان تهيه گرديدند. فعاليت ضدباكتريايى عصارههاى گياهى مورد آزمايش روى سه باكترى گرم مثبت Staphylococcus aureus،Bacillus subtilis) و Rathayibacter toxicus

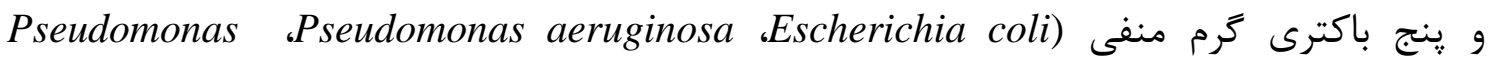
Xanthomonas campestris pv. gseudomonas viridiflava syringae subsp. syringae (campestris

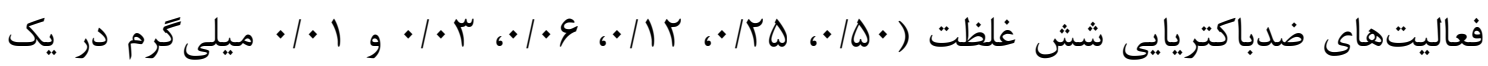
ميلىليتر دى متيل سولفوكسيد) عصارههاى متانولى گياهان در جهار تكرار، با اندازهيرى قطر هاله عدم رشد (بر حسب ميلىمتر) در سطح پيليتها مورد بررسى قرار زرفتند. از دى متيل سولفوكسيد و ديسك خالى به عنوان كنترل منفى استفاده گرديد. 


\section{بررسى فعاليت ضدقارجى عصارههاى متانولى گياهان}

قارجهاى Botrytis cinerea Pyricularia oryzae و Fusarium oxysporum در اين يزوهش مورد

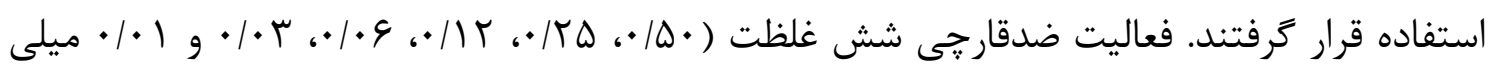
كرم در يك ميلى ليتر دى متيل سولفوكسيد) عصاره متانولى گونههاى گياهى مورد آزمايش با استفاده

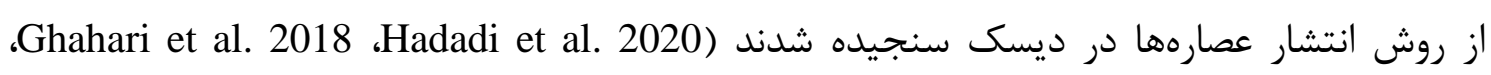

(Ghahari et al. 2017 ،Ghahari et al. 2017

دادهاى آزمايشها در قالب طرح كاملاً تصادفى با استفاده از نرم افزار SPSS20 تجزيه واريانس شده و مقايسه ميانگينها نيز به روش دانكن انجام گرفت. رسم نمودارها با استفاده از نرم افزار 2013 Excel انجام شد.

\section{Results}

يافتهها

\section{فعاليت ياداكسندهاى عصاره گياهان}

فعاليت آنزيمهاى كاتالاز و كاياكول يراكسيداز و يروتيين موجود در عصارههاى اين زياهان در جدول يك نشان داده شده است. بيشترين ميزان فعاليت آنزيم كاتالاز، كاياكول يراكسيداز و : يروتيينهاى محلول در عصاره استخراج شده از دانه هندوانه ابوجهل مشاهده گرديد.

فعاليت ضد راديكالى با استفاده از DPPH در جدول r نشان داده شده است. همانطور كه مشاهده مى Fردد، از بين زياهان مورد آزمايش، دانه هندوانه ابوجهل با \&\&/• = IC50 ميكروگرم بر ميلىليتر داراى بيشترين فعاليت ياداكسندهاى مىباشد.

$$
\text { جدول ا. كاتالاز، كاياكول يراكسيداز و يروتيين عصاره گياهان مورد آزمايش. }
$$

Table 1. Catalase, Guaiacol peroxidase and Protein of the investigated plants extracts.

\begin{tabular}{lccc}
\hline \hline Enzyme assays & $\begin{array}{c}\text { Citrullus } \\
\text { colocynthis } \\
\text { (seeds) }\end{array}$ & $\begin{array}{c}\text { Alhagi } \\
\text { maurorum } \\
\text { (fruit) }\end{array}$ & $\begin{array}{c}\text { Melia } \\
\text { azedarach } \\
\text { (leaves) }\end{array}$ \\
\hline Catalase $^{\mathrm{a}}$ & 1.21 & 0.32 & 0.65 \\
Guaiacol $_{\text {peroxidase }^{\mathrm{b}}}$ & 5.23 & 4.56 & 1.24 \\
Protein $^{\mathrm{c}}$ & 6.24 & 3.82 & 5.52 \\
\hline
\end{tabular}

a) $\mu$ mole activity/min; b) mmole activity /min; c) $\mathrm{mg} / \mathrm{g}$ dry weight 
جدول r. درصد مهار راديكال DPPH، ميزان فنل و فلاونوييد كل عصاره گياهان مورد آزمايش.

Table 2. DPPH radical scavenging activity, total phenol and flavonoid contents of the investigated plants extracts.

\begin{tabular}{|c|c|c|c|}
\hline & $\begin{array}{c}\text { Citrullus } \\
\text { colocynthis } \\
\text { (seeds) }\end{array}$ & $\begin{array}{l}\text { Alhagi } \\
\text { maurorum } \\
\text { (fruit) }\end{array}$ & $\begin{array}{c}\text { Melia } \\
\text { azedarach } \\
\text { (leaves) }\end{array}$ \\
\hline $\mathrm{IC}_{50}(\mu \mathrm{g} / \mathrm{mL})$ & 7.31 & 8.94 & 10.32 \\
\hline Total Phenol Content ${ }^{\mathrm{a}}$ & 43.66 & 46.43 & 18.78 \\
\hline $\begin{array}{l}\text { Total Flavonoid } \\
\text { Content }^{\mathrm{b}}\end{array}$ & 44.23 & 148.75 & 45.36 \\
\hline
\end{tabular}

a) $\mathrm{mg}$ gallic acid equivalents/g dry matter; b) mg quercetin equivalents/g dry matter

$$
\text { ميزان فنل و فلاونوييد كل موجود در عصارهها نيز در جدول r آورده شده است. همانطور كه در }
$$

اثر ضدباكتريايى عصاره متانولى خارشتر، زيتون تلخ و هندوانه ابوجهل در جدولهاى r تا ه نشان داده شده است. همانطور كه در جدول r مشاهده مى گردد، عصاره متانولى دانه هندوانه ابوجهل در ميان باكترىهاى مورد آزمايش، بيشترين فعاليت ضدباكتريايى را روى باكترى R. toxicus و در غلظت ه/ •

$$
\text { ميلى ترم بر ميلىليتر نشان داد. }
$$

جدول r. فعاليت ضد باكتريايى عصاره متانولى دانه هندوانه ابوجهل

Table 3. Antibacterial activity of methanolic extract of Citrullus colocynthis seed

Zone of growth inhibition (mm)

\begin{tabular}{lcccccc} 
& \multicolumn{6}{c}{$\begin{array}{c}\text { Different concentrations of methanolic extract } \\
\text { of Citrullus colocynthis }(\mathrm{mg} / \mathrm{mL})\end{array}$} \\
\cline { 2 - 7 } & 0.50 & 0.25 & 0.12 & 0.06 & 0.03 & 0.01 \\
\hline P. aeruginosa & 12.5 & 11.5 & 10.5 & 10.0 & 9.0 & 8.0 \\
B. subtilis & 10.5 & 9.0 & 7.5 & 0.0 & 0.0 & 0.0 \\
E. coli & 9.5 & 9.0 & 9.0 & 8.5 & 8.0 & 7.0 \\
S. aureus & 11.5 & 10.5 & 10.0 & 10.0 & 9.0 & 9.0 \\
R. toxicus & 14.5 & 12.0 & 10.0 & 9.0 & 8.0 & 7.0 \\
X. campestris & 11.5 & 11.0 & 11.0 & 10.5 & 10.0 & 9.5 \\
P. viridiflava & 10.5 & 10.25 & 10.0 & 9.0 & 8.0 & 7.0 \\
P. syringae & 11.5 & 10.5 & 10.0 & 9.0 & 8.5 & 8.0 \\
\hline
\end{tabular}




$$
\text { جدول fا. فعاليت ضد باكتريايى عصاره متانولى برى زيتون تلخ. }
$$

Table 4. Antibacterial activity of methanolic extract of Melia azedarach leaf.

Zone of growth inhibition $(\mathrm{mm})$

\begin{tabular}{lcccccc} 
& \multicolumn{6}{c}{ Belia azedarach $(\mathrm{mg} / \mathrm{mL})$} \\
\cline { 2 - 7 } & 0.50 & 0.25 & 0.12 & 0.06 & 0.03 & 0.01 \\
\cline { 2 - 7 } & 11.0 & 10.5 & 9.0 & 8.0 & 0.0 & 0.0 \\
P. aeruginosa & 8.5 & 7.5 & 0.0 & 0.0 & 0.0 & 0.0 \\
B. subtilis & 0.0 & 0.0 & 0.0 & 0.0 & 0.0 & 0.0 \\
E. coli & 0.0 & 0.0 & 0.0 & 0.0 & 0.0 & 0.0 \\
S. aureus & 0.0 & 0.0 & 0.0 & 0.0 & 0.0 & 0.0 \\
R. toxicus & 9.5 & 8.25 & 8.0 & 8.0 & 7.5 & 7.0 \\
X. campestris & 0.0 & 0.0 & 0.0 & 0.0 & 0.0 & 0.0 \\
$P$. viridiflava & 0.0 & 0.0 & 0.0 & 0.0 & 0.0 & 0.0 \\
P. syringae & 0.0 &
\end{tabular}

عصاره متانولى برى زيتون تلخ با توجه به جدول \&ٔ، در ميان باكترىهاى مورد آزمايش، بيشترين فعاليت ضدباكتريايى را بر روى باكترى P. aeruginosa با قطر هاله توقف رشد باكترى Iا ميلىمتر نشان داد.

طبق دادههاى جدول ه، تفاوت جندانى در ميزان قطر هاله بازدارنده رشد باكترىها عصاره متانولى ميوه خارشتر در غلظت ه| • ميلى گرم بر ليتر مشاهده نمى

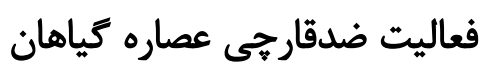

عصاره متانولى استخراج شده از هر يك از اين گياهان در غلظتهاى به كار رفته با روش اغشته كردن ديسك هيج تاثير بازدارندگى روى سه قارج بيمارىزاى Botrytis cinerea Pyricularia oryzae Fusarium oxysporum,

$$
\text { جدول ه. فعاليت ضد باكتريايى عصاره متانولى ميوه خارشتر. }
$$

Table 5. Antibacterial activity of methanolic extract of Alhagi maurorum fruit.

\begin{tabular}{|c|c|c|c|c|c|c|}
\hline \multirow[t]{2}{*}{ Bacterium } & \multicolumn{6}{|c|}{$\begin{array}{c}\text { Different concentrations of methanolic extract } \\
\text { of Alhagi maurorum }(\mathrm{mg} / \mathrm{mL})\end{array}$} \\
\hline & 0.50 & 0.25 & 0.12 & 0.06 & 0.03 & 0.01 \\
\hline P. aeruginosa & 12.5 & 11.5 & 10.5 & 9.5 & 8.5 & 8.0 \\
\hline B. subtilis & 10.5 & 10.0 & 9.5 & 8.0 & 0.0 & 0.0 \\
\hline E. coli & 11.5 & 10.0 & 9.0 & 8.0 & 8.0 & 7.5 \\
\hline S. aureus & 12.0 & 11.0 & 10.0 & 9.5 & 9.0 & 8.0 \\
\hline R. toxicus & 11.0 & 10.75 & 10.5 & 9.5 & 8.25 & 7.0 \\
\hline$X$. campestris & 10.0 & 9.75 & 8.5 & 8.0 & 0.0 & 0.0 \\
\hline P. viridiflava & 10.85 & 0.0 & 9.5 & 9.0 & 8.5 & 8.0 \\
\hline P. syringae & 11.0 & 10.0 & 9.5 & 8.25 & 8.0 & 7.5 \\
\hline
\end{tabular}

Zone of growth inhibition $(\mathrm{mm})$ 


\section{Discussion}

يافتهاى اين يزوهش نشان مىدهند كه عصاره متانولى دانه هندوانه ابوجهل بيشترين فعاليت بازدارندكى را روى كليه باكترىهاى مورد آزمايش دارد. همجنين بيشترين ميزان فعاليت آنزيمهاى كاتالاز و كاياكول يراكسيداز و همجنين بيشترين درصد مهار راديكال DPPH مربوط به دانه هندوانه ابوجهل بوده است.

در تحقيقى فعاليت ضدميكروبى اسانس و عصاره متانولى هندوانه ابوجهل عليه 9 باكترى Escherichia coli Streptococcus pyrogens،Bacillus subtilis Staphylococcus aureus Salmonella ‘Proteus vulgaris ‘Klebsiella pneumoniae ‘Pseudomonous aeruginosa. مورد ارزيابى قرار گرفت. اسانس و عصاره متانولى بيشترين فعاليت Proteus mirabilis،typhi ضدباكتريايى را عليه S. aureus نشان دادند (Doss et al. 2011). در تحقيق ديكرى اثر عصاره متانولى هندوانه ابوجهل عليه باكترىهاى Escherichia coli، Staphylococcus aureus و Klebsiella pneumoniae Proteus mirabilis عصاره بيشترين فعاليت را عليه S. aureus نشان داد (Srivastava et al. 2013). علاوه بر اين، فعاليت ضدباكتريايى عصاره الكلى و آبى برى گياه زيتون تلخ مورد بررسى قرار زرفته، كه نشان داده كه اين عصارهها فعاليت ضدباكتريايى روى باكترىهاى Staphylococcus aureus Bacillus cereus، Sendomonas aeruginosa, Escherichia coli

\section{Conclusion}

بررسى فعاليت ضدباكتريايى، ضدقارجى و گاداكسندهاى عصاره متانولى دانه هندوانهابوجهل، ميوه خارشتر و برى زيتونتلخ عليه هشت باكترى Staphylococcus aureus،Bacillus subtilis و Pseudomonas ‘Pseudomonas aeruginosa ‘Escherichia coli ‘Rathayibacter toxicus Xanthomonas campestris pv. 9 Pseudomonas viridiflava syringae subsp. syringae campestris معمولاً باعث آسيب به محصولات كشاورزى مىشوند نشان داد كه، عصاره دانه هندوانه ابوجهل بيشترين فعاليت بازدارندگى را روى همه باكترىهاى مورد آزمايش دارد. همجنين بيشترين ميزان فعاليت آنزيمهاى كاتالاز و كاياكول يراكسيداز و همجنين بيشترين درصد مهار راديكال DPPH مربوط به دانه هندوانه ابوجهل بوده است. بنابراين عصاره متانولى دانه هندوانه ابوجهل بايد به عنوان يك منبع بالقوه باكترى كش در حوزه كشاورزى مورد توجه قرار كيرد. 


$$
\begin{aligned}
& \text { سياسگزارى } \\
& \text { نويسندكان از مجموعه مديريت يزوهشكده زنتيك و زيست فناورى كشاورزى طبرستان و همكاران آن } \\
& \text { حوزه كه امكانات مورد نياز اين يزوهش را در اختيار قرار دادند صميمانه تشكر مىنمايند. }
\end{aligned}
$$

\section{References}

Abdul-Hafeez EY, Mahmoud AF, Ibrahim OHM (2015) Antibacterial activities and phytochemical screening of Alhagi pseudalhagi. Assiut Journal of Agricultural Sciences 46:33-47.

Al-Zahrani HS, Al-Amer KH (2006) A comparative study on Citrullus colocynthis plant grown in different altitudinal locations in Saudi Arabia. American- Eurasian Journal of Scientific Research 1:1-7.

Atta AH, Mouneir SM (2004) Antidiarrhoeal activity of some Egyptian medicinal plant extracts. Journal of Ethnopharmacology 92:303-309.

Atta AH, Nasr SM, Mouneir SM, Al Wabel NA, Essawy SS (2010) Evaluation of the diuretic effect of Conyza dioscorides and Alhagi maurorum. International Journal of Pharmacy and Pharmaceutical Sciences 2:162-165.

Baskar K, Kingsley S, Vendan SE, Paulraj MG, Duraipandiyan V, Ignacimuthu S (2009) Antifeedant, larvicidal and pupicidal activities of Atalantia monophylla (L.) Correa against Helicoverpa armigera Hubner (Lepidoptera: Noctuidae). Chemosphere 75:355-359.

Benalla W, Bellahcen S, Bnouham M (2010) Antidiabetic medicinal plants as a source of alpha glucosidase inhibitors. Current Diabetes Reviews 6:247-254.

Doss A, Vijayasanthi M, Anand SP, Parivuguna V, Venkataswamy R (2011) Screening of antimicrobial activity of essential oil and methanol extracts of Citrullus colocynthis (L.) Schrad. South Asian Journal of Biological Sciences 1:7-15.

Garriga M, Caballero J (2011) Insights into the structure of urea-like compounds as inhibitors of the juvenile hormone epoxide hydrolase (JHEH) of the tobacco hornworm Manduca sexta: Analysis of the binding modes and structure-activity relationships of the inhibitors by docking and CoMFA calculations. Chemosphere 82:1604-1613.

Ghahari S, Alinezhad H, Nematzadeh GA, Ghahari S (2015) Phytochemical screening and antimicrobial activities of the constituents isolated from Koelreuteria paniculata leaves. Natural Product Research 29:1865-1869.

Ghahari S, Alinezhad H, Nematzadeh GA, Tajbakhsh M, Baharfar R (2017) Biochemical composition, antioxidant and biological activities of the essential oil and fruit extract of Xanthium strumarium Linn. from Northern Iran. Journal of Agricultural Science and Technology 19:1603-1616. 
Ghahari S, Alinezhad H, Nematzadeh GA, Tajbakhsh M, Baharfar R (2017) Chemical composition, antioxidant and biological activities of the essential oil and extract of the Seeds of Glycine max (Soybean) from North Iran. Current Microbiology 74:522531.

Ghahari S, Alinezhad H, Nematzadeh GA, Tajbakhsh M, Baharfar R (2018) phytochemical, antioxidant and biological activities of the essential oil of Astragalus alopecurus pall. fruits from Northern Iran. Journal of Essential Oil Bearing Plants 21:103-115.

Hadadi Z, Nematzadeh GA, Ghahari S (2020) A study on the antioxidant and antimicrobial activities in the chloroformic and methanolic extracts of 6 important medicinal plants collected from North of Iran. BMC Chemistry 14:1-11.

Hadizadeh I, Peivastegan B, Kolahi M (2009) Antifungal activity of nettle (Urtica dioica L.), colocynth (Citrullus colocynthis L. Schrad), oleander (Nerium oleander L.) and konar (Ziziphus spina-christi L.) extracts on plants pathogenic fungi. Pakistan Journal of Biological Sciences: PJBS 12:58-63.

Jain N, Light ME, Van Staden J (2008) Antibacterial activity of hairy-root cultures of Maytenus senegalensis. South African Journal of Botany 74:163-166.

Khalil M, Mohamed G, Dallak M, AL-Hashem F, Sakr H, Eid RA, Adly MA, ALKhateeb M, Banihani S, Hassan Z, Bashir N (2010) The effect of Citrullus colocynthis pulp extract on the liver of diabetic rats a light and scanning electron microscopic study. American Journal of Biochemistry and Biotechnology 6:155-163.

Martins CHZ, Freire MGM, Parra JRP, Macedo MLR (2012) Physiological and biochemical effects of an aqueous extract of Koelreuteria paniculata (Laxm.) seeds on Anticarsia gemmatalis (Huebner) (Lepidoptera: Noctuidae). SOAJ of Entomological Studies 1:49-61.

Mojaz Dalfardi N, Ghodrati Azadi H, Fathi Hafshjani B (2015) Comparison of the effect of edible Citrullus colocynthis fruit powder with metformin on the level of blood glucose in streptozotocin-induced diabetic male rats. The Horizon of Medical Sciences 21:7-12.

Orhan IE, Guner E, Ozcelik B, Senol FS, Caglar SS, Emecen G, Kocak O, Sener B (2012) Assessment of antimicrobial, insecticidal and genotoxic effects of Melia azedarach L. (chinaberry) naturalized in Anatolia. International Journal of Food Sciences and Nutrition 63:560-565.

Rezaei R (2020) Effect of eight essential oils on bacterial canker disease in citrus. Plant Pathology Science 9:30-39.

Rezaie Keikhaie K, Ghorbani S, Hosseinzadeh Z, Hassanshahian M (2018) Antimicrobial activity of methanol extract of Citrullus colocynthis against antibioticresistant Staphylococcus aureus. Advanced Herbal Medicine 4:64-72. 
Saleem R, Rani R, Ahmed M, Sadaf F, Ahmad SI, UL Zafar N, Khane SS, Siddiquie BS, Lubnae AF, Khan SA, Faizie S (2008) Effect of cream containing Melia azedarach flowers on skin diseases in children. Phytomedicine 15:231-236.

Sen A, Batra A (2012) Evaluation of antimicrobial activity of different solvent extracts of medicinal plant: Melia azedarach L. International Journal of Current Pharmaceutical Research 4:67-73.

Srivastava G, Jain R, Vyas N, Mehta A, Kachhwaha S, Kothari SL (2013) Antimicrobial activity of the methanolic extract, fractions and isolated compounds from Citrullus colocynthis (L.) Schrad. International Journal of Pharmacy and Biological Sciences 4:825-833.

Sutherland JP, Baharally V, Permaul D (2002) Use of the botanical insecticide, neem to control the small rice stinkbug Oebalus poecilus (Dallas, 1851) (Hemiptera: Pentatomidae) in Guyana. Entomotropica 17:97-101. 